\title{
Symposium volumes
}

SIR - Anthony Watkinson's interesting and mildly cynical view of conference proceedings (15 November, p.201) represents one side of a very complex phenomaon. David Lodge, in his novel Small World, has explored some of the other activities of conference delegates. Judging from the locations of most US conferences and the attendant social programmes for both delegates and spouses, little time can be spent in the scientific sessions - hence the need for publication of the proceedings.

Whether or not proceedings should always be published, they are certainly wanted. The British Library Lending Division at Boston Spa has for many years tried to collect conference material and now holds about 200,000 volumes of proceedings. The library receives more than 250,000 requests a year for conference papers. A small percentage (less than 5 per cent) of these requests, but inevitably those causing the most trouble, are for papers allegedly presented at a conference but never published. Sometimes, however, the Lending Division holds papers which are never printed in the published proceedings.

I would urge that journal editors refuse to allow authors to quote references to conference papers that are not published unless this is made clear, and that organizers of conferences indicate in advance their publication policy. One way of tracing conferences, especially if the full title is not known for sure, is to consult the Index of Conference Proceedings published by the British Library Lending Division - a monthly keyword index cumulation, annually and quinquennially.

GARTH FRANKLAND

British Library Lending Division,

Boston Spa,

Wetherby, West Yorks LS23 7BQ, UK

SIR - Anthony Watkinson's article (15 November, p.201) on the publication of symposium volumes and conference proceedings explained why publishers like this kind of book. But he only outlined in general terms why many scientists are becoming increasingly hostile to such publications.

At a recent international meeting in the earth sciences, I was approached by no less than five publishers to produce a special issue or book of the symposium that I was convening. It became clear that the publishers were not particularly interested in the academic arguments for publishing this symposium (which happened to be of only average quality), but were largely concerned with printing paper and selling it at high prices to libraries.

The most important detrimental effect of the proliferation of symposium books may in fact be on journals. The best scientific journals are required both by commercial considerations and by duty to their readership to publish at regular intervals. They therefore require a steady flow of high quality manuscripts reporting interesting and original scientific results. A healthy situation for the progress of science in general occurs when such journals have a sufficient supply of papers to be selective and to demand high standards, yet can publish a paper within a reasonable period of time. At present, the amount of highquality research being carried out has reached a plateau and may even be declining in some fields. The symposium books, however, not only publish mediocre papers as implied in Watkinson's article, but also publish some first-class material. Such papers are removed from the reservoir of potential material available to the regular journals. In addition, they are not always reviewed very carefully - a process that is important even for good papers. These effects may well force some journals to lower their standards since they are usually obliged to publish a certain volume of material anyway.

There is no doubt that collections of papers on carefully selected topics can be outstanding contributions to the dissemination of knowledge. I believe, however, that scientists should be much more critical about agreeing to edit and organize symposium volumes. It is clear that most publishers will not agonize much about the various advantages and disadvantages as long as there is a profit to be made. Scientists are the only ones who will have a major effect by saying no more often.

R.S.J. SPARKS

Department of Earth Sciences,

University of Cambridge,

Downing Street,

Cambridge CB2 $3 E Q, U K$

\section{Science and miracles}

SIR - In response to your leading article on miracles (Nature 310, 171; 1984), I think that there are at least two different views of science.

(1) Science as a parlour game, somewhat like chess. One sets the rules, decides who may play and who not, who is the most skilful at it, and even endows some with a certain authority. In such "science" one might state that there are no flying saucers and that miracles do not occur, by simply making it against the rules. Obviously such "science" is limited in its content and truth by the rules until someone changes the rules.

(2) Science as a quest for the truth or at least a working model of the truth. We do not set the rules but try to discover them. We try to achieve some confidence in what we find by analysis, experiments and observations, and not to discolour the truth with our prejudices.

It is reasonable to believe in miracles. The Creator of the Universe might well create a miracle, and miracles have been reported through the ages up to the present times. (Consider the happenings at Lourdes, France.) Moreover, by the criterion of fewest serial steps and most parallel steps, the existence of the Creator is one of the most certain things in science. (Demonstration is beyond the scope of this letter, but consider the statement: "I think, which shows that God is"')

(Consider in this context the statement that this cannot happen because it violates So-and-so's law ...". One wonders: since when does So-and-so run the Universe?).

Much of the bickering in science might perhaps be ascribed to the following of the first view of science by people, rather than realizing that we are in the same boat of ignorance, that one cannot be absolutely certain of anything that one does not absolutely control, and that one is therefore dependent on what the Creator chooses to reveal directly or indirectly.

Welterdreef 161 ,

P.N. KRUYTHOFF

2253 LJ Voorschoten,

The Netherlands

\section{UNESCO and VAT}

SiR - The announcement by the British Foreign Secretary that he has served notice on UNESCO of withdrawal by the United Kingdom from the organization will come as no surprise to anyone, least of all to readers of your leading article (22 November, p. 293).

International considerations apart, the move has more parochial implications for the scientific community, as it comes at a time when strong rumours persist that the Chancellor of the Exchequer has proposed the imposition of Value Added Tax on printed matter. It is not perhaps widely remembered that the proposal was considered when VAT was first instituted but rejected because it infringes the UNESCO charter. Could Britain's projected pull-out from the organization weaken resolve at home to adhere to the principles of the organization? If books, and of course journals such as your own, were so taxed, the effects on education in its widest context would outweigh all the previously inflicted damage caused by previous cuts in financial support from the teaching of literacy up to graduate level. Beyond this, the restriction of information flow that would ensue as library committees stopped journal subscriptions would be paralleled by fewer personal subscriptions and the many learned societies that rely on income from this source would be severely hit.

Were this proposal to be formalized in a finance bill it would be too late to avert its implementation. The time for objections to be voiced is surely now.

STEPHEN G. POSEN

80 Kings Close

London NW4 2JT, UK 